\title{
Fen Bilgisi Öğretmenliği ve İlahiyat Öğrencilerinin Nükleer Santral Sosyo-Bilimsel Konusuyla İlgili İnformal Argümanları
}

\author{
The Informal Argumentation of Theology and Science \\ Education Students about the Socio-Scientific Issue: Nuclear \\ Power Plant
}

\begin{abstract}
Hüseyin EŞ*, Volkan VAROL **
Öz: İnsanlar yaşamlarında sahip oldukları inançlarına veya kanıtlarına dayanarak yargılar ve sonuçlar çıkarmak durumundadırlar, bu nedenle argümantasyon becerileri modern vatandaşlar ve profesyoneller için önemli bir beceri haline gelmiştir ve okullarda kazandırılması gerekmektedir. Bu çalışmada İlahiyat ve Fen bilgisi öğretmenliği lisans programlarında öğrenim görmekte olan öğrencilerin argümantasyon becerilerini incelemek amaçlanmıştır. Araştırmanın çalışma grubunu, kırk yedisi (47) İlahiyat Fakültesi ve yirmi yedisi (27) Eğitim Fakültesi Fen Bilgisi Öğretmenliği olmak üzere toplam yetmiş dört (74) lisans öğrencisi oluşturmaktadır. Araştırmanın veri toplama aracı olarak araştırmacılar tarafindan geliştirilen ve ikisi kapalı biri ise açık uçlu olmak üzere üç sorudan oluşan Nükleer Enerji Karar ve Değerlendirme Formu kullanılmıştır. Veri toplama aracının ilk iki sorusunun analizleri sadece nicel olarak SPSS-21 programı ile yapılmıştır. Üçüncü soru ise önce içerik analizi ile nitel olarak sonrasında ise oluşan kodlar üzerinden SPSS21 programı ile nicel olarak analiz edilmiş̧tir. Araştırma bulguları dikkate alındığında İlahiyat lisans öğrencileri istatiksel olarak anlamlı bir fark ile nükleer santralin kurulmasını, fen bilgisi öğretmenliği öğrencileri ise kurulmamasını istemektedirler. Araştırma sonuçları dikkate alındığında gerek İlahiyat gerekse de Fen bilgisi öğretmenliği lisans öğrencilerinin büyük çoğunluğunun iyi düzeyde informal argümantasyon becerisine sahip olmadığı ve Sosyo-bilimsel konuların çok boyutlu yapısına uygun argüman üretemediği görülmüştür.
\end{abstract}

Anahtar Kelimeler: Sosyo-bilimsel konular, argümantasyon, informal argümantasyon, Lakatos'un bilimsel araştırma programları, nükleer

\begin{abstract}
People have to make judgments and conclusions based on their beliefs or evidence in their lives. Therefore, argumentation skills have become an important skill for modern citizens and professionals and need to be acquired in schools. This study was conducted in order to examine the argumentation skills of the students studying in theology and science education undergraduate programs. The study group consisted of, forty-seven (47) Theology students, twenty-seven (27) Science Education students, Faculty of Education, in the total of seventy-four (74) undergraduate students. The data collection tool of this study is the Nuclear Energy Decision and Evaluation Form (NEDEF), which consists of three questions, two of which are closed and one of which is open-ended. Answers of first two questions of the form were entered the SPSS-21 program as the participants filled. On the other hand, for the third question, content analysis was performed and then frequencies of the codes entered to SPSS-21 program. The results of the study indicate that theology students support the establishment of the nuclear power plant than science education students and this difference is found to be statistically significant. It is seen that the majority of the undergraduate students of both theology and science education do not have good informal argumentation skills and cannot create arguments good enough for multidimensional structure of SSI.
\end{abstract}

Keywords: Socio-scientific issues, argumentation, informal argumentation, Lakatos' scientific research programs, nuclear

\footnotetext{
* Dr. Öğr. Üyesi, Sinop Üniversitesi, Eğitim Fakültesi, Sinop-Türkiye, ORCID: 0000-0001-8294-5080, e-posta: huseyines@sinop.edu.tr.

** Dr. Öğr. Üyesi, Sinop Üniversitesi, Eğitim Fakültesi, Sinop-Türkiye, ORCID: 0000-0002-2493-8904, e-posta: vvarol@sinop.edu.tr.
} 


\section{Giriş}

Fen bilimleri ya da teknoloji ile ilişkili olan toplumsal sorunlar yakın geçmişte ülkelerin dikkatini çekmiştir. Klonlama, kök hücre çalışmaları, genom projesi, küresel ısınma, alternatif yakıtlar (Sadler, 2004a; Sadler ve Zeidler, 2005; Sadler ve Donnelly, 2006), iklim değişikliği, nükleer enerji gibi toplumda yer alan bilimsel, açı uçlu (Presley ve diğerleri, 2013) ve bireylerde ikilem oluşturan toplum ile bilimi ve teknolojiyi buluşturan bu konular Sosyo-bilimsel Konular(SBK) olarak tanımlanmaktadır (Sadler, 2004a). SBK'nın biyoloji (klonlama ve genetik mühendisliği gibi), kimya (DDT ve Dioksin gibi), tıp (Gen terapisi ve aşı sorunu gibi), fizik (nükleer güç gibi) ve çevre bilimi (küresel 1sınma gibi) gibi birçok disipline hitap ettiği ve yerelden küresele kadar geniş bir yelpazede etkilerinin görüleceği dikkate alındığında bu konuları üzerinde önemle durulması ve tartışılması gereken konular olarak değerlendirmek mümkündür (Chang Rundgren ve Rundgren, 2010). Bazı tartışmalı konular küresel özellik taşıması nedeniyle Dünya çapında farklı bölgelerde yaşayan insanların tartışma konusu olabilirken, bazı SBK ise bulunduğu bölgeyi ilgilendirmekte ve yerel olarak tartışllabilmektedir (Chang Rundgren ve Rundgren, 2010).

Bireyler çeşitli SBK ile ilgili eleştirel düşünme ve karar verme becerilerini işe koşmak zorunda kalabilmektedirler (Chang Rundgren ve Rundgren, 2010). Bu süreçte bireylerin tartışma, akı1 yürütme ve karar verme becerilerini geliştirmelerinde ve toplumsal sorunlara sosyal, politik, bilimsel gibi birçok açıdan bakarak bilinçli kararlar verebilmelerinde yani fen okuryazar birey olmalarında SBK'nın önemli bir bağlam olduğu vurgulanmaktadır (Hodson, 2003; Zohar ve Nemet, 2002; Sadler ve Zeidler, 2005). Demokratik bir yaklaşımı benimseyen fen eğitimcileri, fen öğretiminde karar vermenin önemi üzerinde durmuşlardır. Bilim ve teknoloji ile ilgili toplumsal sorunlarda ve geleceği etkileyen durumlarda bilinçli kararlar verebilme fen okuryazar birey olmanın bir göstergesi niteliği taşımaktadır (Bossér ve diğerleri, 2015; Chang ve Chiu, 2008; Eggert ve Bögeholz, 2010; Lee, 2007; Sadler, 2004a; Zeidler ve diğerleri, 2005). Nitekim SBK kapsamında sosyal ve politik yönden yerel, ulusal ve küresel boyutlara sahip olma, risk faktörünün önemsendiği fayda-maliyet analizlerini içerme, sürdürülebilir kalkınmayı gerektirme, değerleri ve ahlaki muhakemeyi içerme ve gerçek hayat bağlamında konular olma gibi özellikler de yer almaktadır (Grace ve Ratchliffe, 2002). Birçok araştırmacı, fen eğitiminde ahlak ve etik boyutlarının da SBK ile ilgili karar verme sürecinde önemli ölçüde etkisinin olduğunu belirtmiştir (Bell ve Lederman, 2003; Sadler, 2003; Sadler, 2004b; Zeidler ve diğerleri, 2002).

Özellikle son yıllarda insanların nasıl karar verdiklerini ve davrandıklarını anlamak ve bireylerin düşünme becerilerini geliştirmek için düşünme, argümantasyon ve bu ikisinin ilişkisi ön plana çıkmıştır (Chang ve Chiu, 2008).

İnsanlar yaşamlarında sahip oldukları inançlarına veya kanıtlarına dayanarak yargılar ve sonuçlar çıarmak durumundadırlar (Kuhn, 1993), bu nedenle argümantasyon becerileri modern vatandaşlar ve profesyoneller için önemli bir beceri haline gelmiştir ve okullarda kazandırılması gerekmektedir (Driver, Newton ve Osborne, 2000; Nussbaum, 2002). Argümantasyon becerilerinin öneminin bilinmesine rağmen öğrencilerin bu becerilere ne düzeyde sahip oldukları tam olarak bilinmemektedir. Bu nedenle öğrencilerin argümantasyon becerilerine ne düzeyde sahip olduklarını araştırmak bir gereklilik olarak karşımıza çıkmaktadır. Bu çalışma işte bu gerekçeler doğrultusunda farklı lisans programlarında (ilahiyat ve fen bilgisi öğretmenliği) öğrenim görmekte olan öğrencilerin argümantasyon becerilerini incelemek amacıyla yapılmıştır.

\section{Kavramsal çerçeve}

Bu bölümde, çalışmanın teorik bağlamının anlaşılır hale gelmesi amacıyla ayrı başlıklar altında formal ve informal argümantasyon arasındaki farklar vurgulanmış; sonrasında, informal argümantasyonun göstergeleri ve Lakatos'un programlarının teorik modeli açıklanmıştır. Bunlara ek olarak, neden bu çalışmada informal argümantasyonu analiz etmek için Lakatos'un programlarının seçildiği de açıklanmıştır.

\section{Formal ve informal argümantasyon arasindaki farklılıklar}

Kavram olarak argümantasyon düşünmemenin özüdür ve "argüman olarak düşünmek" uzun zamandan beri vardır (Chang ve Chiu, 2008). Öyle ki Platon, Socrates, Aristoteles gibi filozoflar 
argümanların düşünmenin çekirdeğini oluşturduğunu iddia etmişlerdir (Kuhn, 1991). O dönemlerden yirminci yüzyılın ortalarına kadar formal mantık en iyi düşünce modeli olarak benimsenmiştir. 1958 yılında ise Toulmin yayınladığı "The Uses of Argument" adlı kitabında formal mantığın sınırları ile kendi argümantasyon modelini ortaya koymuş ve argümantasyonu bir tür düşünme biçimi olarak kullanmanın avantajlarını vurgulamıştır. Gerekçelendirmenin argümantasyonun özü olduğu fikrine dayanarak (Means ve Voss, 1996) argümantasyonun gerekçelendirme sürecini kapsayan bir söylem biçimi olduğu söylenebilir (Halpern, 1996; Voss ve Means, 1991). Günümüzde ise gerekçelendirme formal ve informal olarak sinıflandırılmaktadır (Means ve Voss, 1996; Sadler, 2004a; Voss, Perkins ve Segal, 1991; Zohar ve Nemet, 2002).

Formal ve informal argümantasyon arasındaki farkl1l1klara genel olarak değinmek gerekirse öncelikli olarak formal argümantasyonda tüm öncüller sabittir ve öncülün herhangi bir içeriğinin eklenmesi ve silinmesine izin verilmez. Fakat informal gerekçelendirmenin bilişsel ve duyuşsal özellikler içermesi nedeniyle (Perkins, Faraday ve Bushey, 1991; Sadler, 2004a; Voss, 1991), informal argümantasyon sürecinde bireyler kişisel bilgi ve inanışlarına, gazetelerden ders kitaplarından ya da yaşam deneyimlerinden vb. edindikleri malumatlara dayanarak öncüllerini değiştirebilir (Perkins ve diğerleri, 1991). İkinci olarak ise gerekçelendirme yapısı açısından, formal argümantasyon normalde doğrusal bir yapı olarak ilerler; ancak bu tür bir gerekçelendirme modelinin günlük yaşama uygun bir pratik olduğu düşünülmemektedir (Nickerson, 1991). Günlük yaşamlarında insanlar çoğu zaman birden fazla kaynaktan edindikleri malumatları informal gerekçelendirme yolu ile alır ve doğası gereği daha geçici olabilecek bir sonuca varırlar. Sonuç olarak formal gerekçelendirme doğrusal bir yapıya sahipken informal gerekçelendirme ise çok dallı bir ağaca benzetilebilir (Means ve Voss, 1996; Perkins ve diğerleri, 1991).

\section{Lakatos'un bilimsel araștırma programları}

Argümantasyon ile ilgili yapılan çalışmalar incelendiğinde argümanların analizi sürecinde genellikle Toulmin'in argümantasyon modelinin kullanıldığı görülmektedir (Erduran, Simon ve Osborne, 2004; Eş ve Varol, 2018; Jimenez-Aleixandre, 2002; Kelly ve Chen, 1999; Kelly, Druker ve Chen, 1998; Osborne, Erduran ve Simon, 2004; Simonneaux, 2001; Tirri ve Pehkonen, 2002). Ancak bu modeli kullanan bazı araştırmacılar (Chang ve Chiu, 2008; Erduran ve diğerleri, 2004; Kelly ve Chen, 1999; Kelly ve diğerleri, 1998) argümanların analizi sürecinde sorunlar yaşandığını ifade etmişlerdir. Bu sorunların üstesinden gelebilmek amacıyla Chang ve Chiu (2008) argümanların analizi için alternatif bir yapı olarak Lakatos'un bilimsel araştırma programlarını benimsemişlerdir. Lakatos'un programları dört bileşenden oluşmaktadır: (1) programların çekirdeğinde/merkezinde yer alan Katı Çekirdek (KÇ) (Hard Core (HC)), (2) KÇ’yi çevreleyen koruyucu kuşak (KK) (protective belt (PB)) ve koruyucu kuşağı oluşturan (3) pozitif keşif (PK) (positive heuristic (PH)) ile (4) negatif keşif (NK) (negative heuristic (NH)) (Lakatos, 1970). KÇ, teorinin özü ve temelidir ve programlarda saldırılması ve dejenere edilmesi zor olan kesin ve değişmez özelliklere sahiptir; KK, KÇ'nin saldırıya uğramasını önlemek için yardımcı hipotezlerden oluşur; NK teorinin eksik, hatalı ya da sıkıntılı yönlerini ifade ederken PK, teoriyi genişleten bir fonksiyona sahiptir. KK, teori ile ilgili sıkıntılı yönleri değerlendirmede ve NK ve PK kullanarak absorbe etmede önemli bir işleve sahiptir. Programın bileşenleri Şekil 1'de görülmektedir. 


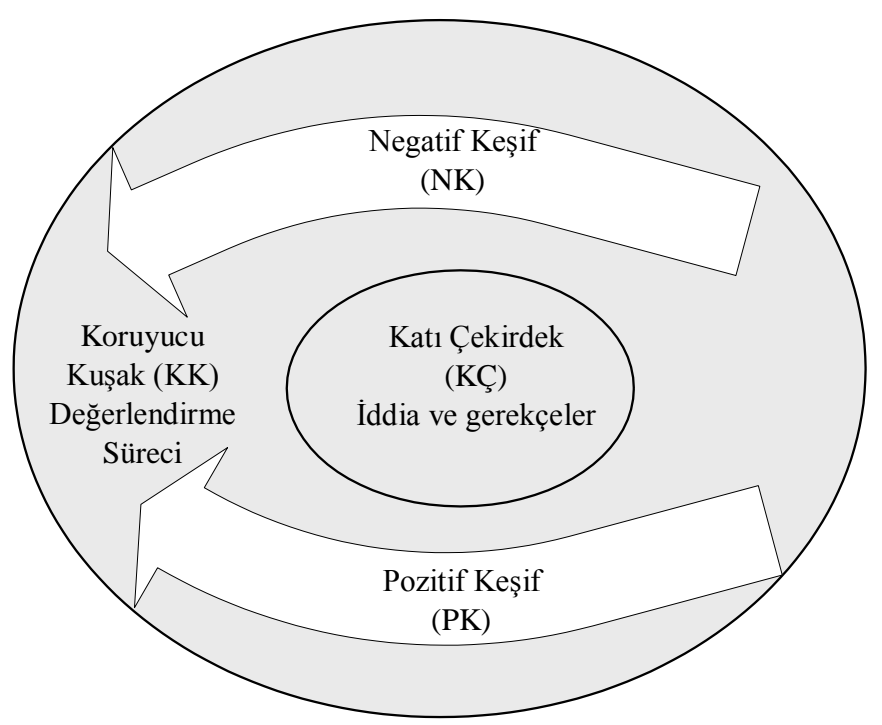

Şekil 1. Lakatos'un Bilimsel Araştırma Programlarının Tasarımı (Chang ve Chiu, 2008)

Chang ve Chiu (2008) informal argümantasyonun beş göstergesini tanımlamışlar ve bu göstergelerin Lakatos'un bilimsel araştırma programları ile olan ilişkisini Tablo 1'de görüldüğü şekilde sunmuşlardır.

Tablo 1.

Lakatos'un Bilimsel Araştırma Programları ve İnformal Argümantasyonun Beş Göstergesi Arasındaki İlişki

\begin{tabular}{lll}
\hline $\begin{array}{l}\text { Lakatos'un bilimsel } \\
\text { araştırma programlarının } \\
\text { bileşenleri }\end{array}$ & $\begin{array}{l}\text { İnformal } \\
\text { argümantasyon } \\
\text { becerileri }\end{array}$ & Tanım \\
\hline Katı Çekirdek (KÇ) & $\begin{array}{l}\text { (1) İddiada bulunma } \\
\text { (2) Destekleyici }\end{array}$ & $\begin{array}{l}\text { Bireyler bir veya daha fazla gerekçe } \\
\text { ile desteklenmiş kendi iddialarını } \\
\text { belirtirler. }\end{array}$ \\
Negatif Keşif (NK) & $\begin{array}{l}\text { (3) Karşı argütumanları } \\
\text { sunma }\end{array}$ & $\begin{array}{l}\text { İddiaya dayanarak, bireyler ortaya } \\
\text { koydukları iddianın sınırlılıklarını } \\
\text { bilirler. }\end{array}$ \\
Pozitif Keşif (PK) & $\begin{array}{l}\text { (4) Niteleyicileri } \\
\text { sunma }\end{array}$ & $\begin{array}{l}\text { ilerleyişini veya genişletilmesini } \\
\text { bilirler. } \\
\text { Bireyler argümanları değerlendirir. }\end{array}$ \\
Koruyucu Kuşak (KK) & (5) Argümanları & \\
\hline
\end{tabular}

\section{Yöntem}

$\mathrm{Bu}$ araştırmada ilahiyat ve fen bilgisi öğretmenliğinde öğrenim görmekte olan lisans öğrencilerinin informal argümantasyon becerilerinin incelenmesi amaçlanmıştır. $\mathrm{Bu}$ amaç doğrultusunda araştırma yöntemi olarak durum çalışması tercih edilmiştir. Araştırmanın yöntemi ile ilgili bölümler detaylıca açıklanarak ayrı başlıklar halinde sunulmuştur. 


\section{Çalışma grubu}

Araştırmanın çalışma grubunu, kırk yedisi (47) İlahiyat Fakültesi ve yirmi yedisi (27) Eğitim Fakültesi Fen Bilgisi Öğretmenliği olmak üzere toplam yetmiş dört (74) lisans öğrencisi oluşturmaktadır. Çalışma grubunun tamamı mezun olma durumunda olan öğrencilerdir. Araştırmanın çalışma grubunun İlahiyat ve Fen Bilgisi Öğretmenliği öğrencilerinden oluşturulma sebebi din ağırlıklı öğrenim gören lisans öğrencileri ile bilim ağırlıklı öğrenim gören lisans öğrencilerinin informal argümantasyon becerilerinin karşılaştırılmasıdır.

\section{Veri toplama aracı}

Araştırmanın veri toplama aracını ikisi kapalı biri ise açık uçlu olmak üzere üç sorudan oluşan Nükleer Enerji Karar ve Değerlendirme Formu (NEKDF) oluşturmaktadır. NEKDF nükleer santral ile ilgili kısa bir bilgilendirme içermektedir. Bu bilgilendirmenin ardından katılımcılara iki kapalı uçlu soru sorulmuştur. Bu soruların birinde sıfirdan (0) ona (10) kadar $(0,1,2,3,4,5,6,7,8,9,10)$ değerlerin bulunduğu bir skala yer almaktadır. Skalada sıfır değeri nükleer santral kurulumunun kesinlikle gerçekleşmemesi, beş (5) değeri kararsızlığı, on (10) değeri ise santral kurulumunun kesinlikle gerçekleşmesini ifade etmektedir. Kararsızlık değeri olan beşten sıfıra ya da ona doğru gidildikçe kararlılık artmaktadır. Katılımcılardan kararlarını bu skalada işaretlemeleri istenmiştir. $\mathrm{Bu}$ sayede katılımcıların verdikleri kararlarındaki katılıkları/kararlılıkları öğrenilmeye çalışılmıştır. Diğer soruda ise katılımcılara "yaşadığınız şehirde nükleer santral ile ilgili bir oylama yapılsaydı oyunuz ne olurdu?" sorusu yöneltilmiştir. Bu soru için katılımcılara sadece yapılmalı ve yapılmamalı olmak üzere iki seçenek sunulmuştur. $\mathrm{Bu}$ sayede katılımcıların KÇ iddialarının belirlenmesi amaçlanmıştır. Formun üçüncü ve son sorusu ise açık uçludur ve bu soruda katılımcılardan verdikleri kararı olumlu ve olumsuz yönleri ile tartışmaları/değerlendirmeleri istenmiştir. Bu soruya verilen cevaplar ile de katılımcıların KÇ gerekçeleri, PK, NK ve KK'lari belirlenmeye çalışılmıştır.

\section{Verilerin analizi}

Veri toplama aracının ilk iki sorusunun analizleri sadece nicel olarak SPSS-21 programı ile yapılmıştır. Üçüncü soru ise önce içerik analizi ile nitel olarak sonrasında ise oluşan kodlar üzerinden SPSS-21 programı ile nicel olarak analiz edilmiştir. Üçüncü sorunun nitel analiz süreci şu şekilde gerçekleşmiştir. Söz konusu süreçte öncelikli olarak katılımcıların formları temsili olarak (mesela ilk İlahiyat öğrencisinin kağıdı için İ1, ilk Fen Bilgisi öğrencisinin kağıdı için F1 gibi) yeniden adlandırılmıştır. Sonrasında ise üçüncü soruya verilen cevaplar içerik analizine tabi tutulmuştur. İçerik analizi, analiz sürecinde ortaya çıkan kodlar ile yapılabileceği gibi hazır kodlar kullanılarak da yapılabilir (Patton, 2014). Bu çalışmanın içerik analizi sürecinde katılımcıların informal argümantasyon becerilerini belirlemek amaciyla Chang ve Chiu (2008) tarafindan Lakatos'un bilimsel araştırma programlarından geliştirilen KÇ gerekçe, PK, NK ve KK hazır olarak kullanılmıştır. Katılımcıların NEKDF'nin üçüncü sorusuna verdikleri cevaplar analiz edilerek konu ile ilgili KÇ gerekçe, PK, NK ve KK'ları belirlenmiştir. Sonrasında ise katılımcıların oluşturdukları KÇ gerekçe, $\mathrm{PK}$, NK'lar kendi içerisinde tekrar içerik analizine tabi tutulmuştur. $\mathrm{Bu}$ sayede katılımcıların hangi SBK boyutlarını kullandıkları belirlenmeye çalışılmıştır. Katılımcıların KÇ gerekçe, PK, NK'larında kullandıkları SBK'nın boyutları Chang Rundgren ve Rundgren (2010)'ın geliştirmiş oldukları SÇE-BEP (SEE-SEP) modelinden geliştirilen ve aşağıda ayrıntıları verilen SÇE-BTEP modelinin konu alanları kullanılarak analiz edilmiştir.

\section{Sosyoloji/kültür (S) (Sociology/culture)}

İnsanların muhakeme ya da argümantasyon süreçlerinin onların toplumsal ya da kültürel geçmişlerinden etkilenebileceği kaçınılmazdır. Mesela, batı kültüründe cep telefonu iletişim alanında hayatımızın vazgeçilmez bir unsuru iken Amazon yağmur ormanlarında yaşayan insanlar henüz gerekli şebekenin kurulmamış olmasından ya da oradaki insanların buna gereksinim duymamasından dolayı cep telefonunun işe yaramaz bir icat olduğunu düşünebilirler (Chang Rundgren, 2011). 


\section{Cevre (C) (Environment)}

Günümüzde araba kullanımı, nükleer enerji, küresel ısınma ve ayrıca GDO'lar gibi giderek daha fazla sayıda SBK, çevresel ve ekolojik konu alanlarıyla doğrudan ilgileri ile ön plana çıkmaktadır (Chang Rundgren ve Rundgren, 2010). Bu durum çevrenin bilim konu alanından farklı bir boyut olarak ele alınmasını sağlamıştır.

\section{Ekonomi (E) (Economy)}

SBK'yı tartışırken öne çıkan ve bireylerin kararlarını etkileyen önemli boyutlardan biri de ekonomidir. Mesela yoksul bir ülkede sivrisinekleri öldürmek ve sitma sorununu ortadan kaldırmak için DDT kullanımı bazı bireyler için kabul edilebilir, çünkü zayıf ekonomik durum bireylerin DDT'nin gelecekteki muhtemel zararlarını göz ardı ederek insanları mevcut hastalıktan korumayı öncelik olarak görmelerine neden olabilir (Chang Rundgren ve Rundgren, 2010).

\section{Bilim (B) (Science)}

Bir fen eğitimcisi için öğrencilerin günlük yaşamlarında bilimsel bilgileri uygulamalarını sağlamak önemli hedeflerden biridir. SBK öğrencilere öğrendiklerini uygulayabilmeleri için gerçek bir bağlam görevi görebilir. Bu nedenle, farklı konulardaki (yani biyoloji, kimya, teknoloji, tıp vb.) bilimsel bilgiler, bireylerin düşünme süreçlerine dâhil edilmelidir (Chang Rundgren ve Rundgren, 2010).

\section{Teknoloji $(T)$}

Chang Rundgren ve Rundgren (2010) geliştirdikleri modelde teknolojiyi bilim içerisinde ele almış ve teknolojiyi sanki bir bilim dalı gibi değerlendirmişlerdir. Hâlbuki teknoloji ve bilim yakın etkileşim içerisinde olmakla birlikte birbirinden farklı alanlardır (Eş, 2017). Bu nedenle Chang Rundgren ve Rundgren (2010) tarafindan geliştirilen SÇE-BEP modeline teknoloji konu alanı da eklenerek bu çalışmada SÇE-BTEP modeli olarak revize edilmiş ve kullanılmıştır. Benzer biçimde özellikle fen eğitimi alanında son dönemin popüler yaklaşımı olan FeTeMM yaklaşımında da fen ile teknoloji ayrı alanlar olarak ele alınmaktadır. Teknoloji hem diğer disiplinlerden (fen, matematik, kültür vb.) elde edilen kavram ve becerileri kullanan bir bilgi türü hem de materyalleri, enerjiyi ve araçları kullanarak belirlenen bir ihtiyacı gidermek veya belirli bir problemi çözmek için bu bilginin insanlık hizmetine sunulması olarak ifade edilmektedir. Bununla birlikte teknoloji insanların istek ve ihtiyaçlarını gidermek için araçlar, yapılar veya sistemlerin geliştirildiği ve değiştirildiği bir süreçtir (MEB, 2005).

\section{Etik/Ahlak (E) (Ethics/Morality)}

Günümüzde SBK ile ilgilenirken, etik ve ahlaki kaygılar tartış1lmakta ve vurgulanmaktadır. Bu konu alanının içerisinde hayvan ve insan haklarının da ele alınması önemlidir (Chang Rundgren, 2011).

\section{Politik (P) (Policy)}

Bazı insanlar SBK ile ilgili kararlarını hükümet tarafından uygulanan politikaya veya yasalara göre almaktan yana olabilir. Başka bir ifadeyle, bu şekilde karar alan insanlar hükümet veya otoritelerine daha fazla güvendiğini ve inandığını söyleyebiliriz. Mesela, bazı insanlar hükümetlerinin yeteneğine güvendikleri için yeni bir nükleer enerji santrali geliştirilmesini destekleyebilir (Chang Rundgren ve Rundgren, 2010).

Araştırmanın nitel verileri araştırmacılar tarafindan bağımsız olarak analiz edilmiştir. Sonrasında ise araştırmacılar bir araya gelerek iki araştırmacı tarafından oluşturulan kodlar karşılaştırılmış ve araştırmacıların çelişkiye düştüğü durumlar yeniden değerlendirilerek kodlara son şekli verilmiştir. Bu şekilde yapılan veri analizinin güvenirliği; [(Görüş birliği) / (Görüş birliği + Görüş ayrılığı)] x 100 formülü kullanılarak hesaplanmıştır (Miles ve Huberman, 1994). Kodlayıcılar arasındaki ortalama güvenirlik \% 96 olarak bulunmuştur.

NEKDF'nin üçüncü sorusu ile ilgili analiz sürecine dair örnek katılımcı cevapları Tablo 2'de sunulmuştur. 
Tablo 2.

Örnek Katılımc1 Cevapları

\begin{tabular}{lll}
\hline Boyutlar & Örnek ifade & Bileşen \\
\hline Sosyal & "Refah seviyesi yüksek olan, ... ülkelerin santralleri mevcut” (İ34) & PK \\
Çevre & "çevreye verdiği zarar ...” (F19) & NK \\
Ekonomi & "Nükleer santral kurulmalı çünkü ülkemizi ekonomik açıdan & KÇ gerekçe \\
& geliştireceğine inanıorum” (İ45) & \\
Bilim & “... genler üzerinden gelecek nesillere aktarılacak,...” (F23) & PK \\
Teknoloji & "Nükleer santral bir ülkenin ... teknolojik açıdan ilerlemesi için & NK \\
& önemlidir” (İ15) & \\
Etik & "inancım gereği ... bunu destekleyemem” (İ44) & PK \\
Politik & "Devletimiz buna karar verdiyse ...” (F20) & PK \\
\hline
\end{tabular}

Bulgular

Katılımcıların kararları ve kararlarındaki kararlılıklarına ilişkin bulgular

Araştırma kapsamında veri toplama aracı olarak kullanılan form ile katılımcıların nükleer santral kurulumu ile ilgili kararları yapılmalı/yapılmamalı şeklinde belirlenmiştir. Katılımcıların nükleer santral ile ilgili verdikleri kararların betimsel istatistikleri Tablo 3 'de sunulmuştur.

Tablo 3.

Katılımcıların Nükleer Santrali Destekleme Kararlarının Betimsel İstatistikleri

\begin{tabular}{llll}
\hline & Ortalama & N & SS \\
\hline Nükleer Santral yapı1sın & 8.64 & 42 & 1.65 \\
Nükleer Santral yapılmasın & 1.25 & 32 & 1.69 \\
\hline Total & 5.45 & 74 & 4.04 \\
\hline
\end{tabular}

Genel olarak bakıldığında araştırmaya katılan yetmiş dört $(\mathrm{N}=74)$ katılımcının otuz ikisi $(\mathrm{n}=32, \% 43.2)$ nükleer santral yapılmamalı görüşünü ifade ederken kırk ikisi $(\mathrm{n}=42, \% 56.8)$ yapılmalı görüşünü ifade etmiştir. Katılımcıların skala değerlerine bakıldığında ise nükleer santralin kurulması yönünde oy kullananların desteği ortalama 8.64 (ss=1.65) iken kurulmamas1 yönünde oy kullananların desteği ortalama 1.25 (ss=1.69) olarak bulunmuştur. Tüm katılımcıların ortalaması ise kararsız değerine (5) yakın bir değer olan 5.45 (ss=4.04) olarak belirlenmiştir. Program bazında katılımcıların Nükleer Santrali destekleme düzeylerinin betimsel istatistikleri Tablo 4'de sunulmuştur.

Tablo 4.

Lisans Değiş̧kenine Göre Katılımcıların Nükleer Santrali Destekleme Düzeylerinin Betimsel İstatistikleri

\begin{tabular}{llll}
\hline & Ortalama & N & SS \\
\hline İlahiyat Öğrencileri & 6.68 & 47 & 3.67 \\
Fen Bilgisi Öğretmenliği & 3.30 & 27 & 3.80 \\
\hline Genel & 5.45 & 74 & 4.04 \\
\hline
\end{tabular}

Durum, program bazında ele alındığında araştırmaya katılan kırk yedi ilahiyat öğrencisinin on dördü ( $\mathrm{n}=14, \% 29.8)$ nükleer santral yapılmamalı görüşünü ifade ederken otuz üçü $(n=33, \% 70.2)$ yapılmalı görüşünü ifade etmiştir. Yirmi yedi fen bilgisi öğrencisinin ise on sekizi $(n=18, \% 67)$ nükleer santral yapılmamalı görüşünü ifade ederken dokuzu $(n=9, \% 33)$ yapılmalı görüşünü ifade etmiştir. Katılımcıların kayıtlı oldukları bölüme göre nükleer santralin kurulmasına yönelik destekleri incelendiğinde ise İlahiyat Fakültesi lisans öğrencilerinin Sinop'a nükleer santralin kurulmasına yönelik destekleri ortalama $6.68(\mathrm{ss}=3.67)$ bulunmuştur. Bunun yanında Fen Bilgisi öğretmenliği programına kayıtlı lisans öğrencilerinin nükleer santral 
kurulmasına destekleri ortalama 3.30 (ss=3.80) bulunmuștur. İlahiyat ve Fen Bilgisi öğretmenliği lisans öğrencilerinin nükleer santral kurulmasına verdikleri destekler birbirinden farklıdır. $\mathrm{Bu}$ farkın istatistiksel olarak anlamlı olup olmadığını belirlemek için bağımsız örneklem t-testi yapılmıştır.

Tablo 5.

Katılımcıların Nükleer Santrali Destekleme Düzeylerinin Lisans Değişkenine Göre Bağımsız Örneklem T-Testi

\begin{tabular}{lllll}
\hline & Ortalama fark1 & $\mathrm{t}$ & $\mathrm{Sd}$ & $P$ \\
\cline { 2 - 5 } İlahiyat- Fen Bilgisi Öğretmenliği & 3.39 & 3.77 & 72 & .00 \\
\hline
\end{tabular}

Tablo 5'de görüldüğü üzere İlahiyat Fakültesi lisans öğrencileri nükleer santral yapılmasına Fen bilgisi öğretmenliği lisans öğrencilerinden daha fazla destek vermektedirler ve bu farkın istatistiksel olarak anlamlı olduğu bulunmuştur $(\mathrm{t}(72)=3.77, \mathrm{p}=0.00)$. Katılımeıların nükleer santralin kurulmasına yönelik desteklerinde ne kadar kararlı olduklarını değerlendirmek için elde edilen veriler ölçeğin orta noktası olan 5 (kararsızım) test değeri seçilerek tek örneklem t-testi yapılmıştır.

Tablo 6.

Nükleer Santrali Destekleme Düzeylerinin Tek Örneklem T-Testi

\begin{tabular}{llllll}
\hline & Ortalama fark1 & SS & T & sd & P \\
\hline Genel & 0.45 & 4.04 & 0.95 & 73 & 0.35 \\
İlahiyat & 1.68 & 3.67 & 3.14 & 46 & $0.00^{*}$ \\
Fen Bilgisi Öğretmenliği & -1.70 & 3.80 & -2.33 & 26 & $0.03^{*}$ \\
\hline Test Değeri=5 & & & & \\
$*$ p değeri 0.05 seviyesinde anlaml1 (2 tailed) & & & & \\
\hline
\end{tabular}

Tablo 6 incelendiğinde katılımcıların desteklerinin test değeri 5 'ten istatistiksel olarak anlamlı bir fark oluşturmadığ görülmektedir $(\mathrm{t}(73)=0.95, \mathrm{p}=0.35)$. Ancak katılımcıların lisans programları göz önüne alındığında İlahiyat Fakültesi öğrencileri nükleer santralin kurulmasını desteklemede kararlı $(\mathrm{t}(46)=3.14, \mathrm{p}=0.00)$ iken, Fen bilgisi öğretmenliği öğrencileri nükleer santralin kurulmasına karşı duruşlarını kararlı bir şekilde ortaya koymaktadırlar $(\mathrm{t}(26)=-2.33$, $\mathrm{p}=0.03)$.

Katılımcıların informal argümantasyon becerilerine ilişkin bulgular

Katılımcıların nükleer santral ile ilgili KÇ gerekçelerinin SÇE-BTEP modeline göre dağılımı Tablo 7'de sunulmuştur.

Tablo 7.

Katılımcıların KÇ Gerekçelerinin SÇE-BTEP Modeline Göre Dağılımı

\begin{tabular}{|c|c|c|c|c|c|c|}
\hline & \multicolumn{2}{|c|}{ İlahiyat } & \multicolumn{2}{|c|}{ Fen Bilgisi } & \multicolumn{2}{|c|}{ Toplam } \\
\hline & Yapılmal & Yapılmamal & Yapılmal & Yapılmamal & Yapılmal & Yapilmamal \\
\hline Boyutlar & $\begin{array}{c}1 \\
\text { (f) }\end{array}$ & $\begin{array}{c}1 \\
\text { (f) }\end{array}$ & $\begin{array}{c}1 \\
\text { (f) }\end{array}$ & $\begin{array}{c}1 \\
\text { (f) }\end{array}$ & $\begin{array}{c}1 \\
\text { (f) }\end{array}$ & $\begin{array}{c}1 \\
\text { (f) }\end{array}$ \\
\hline Sosyoloji & 2 & 0 & 0 & 0 & 2 & 0 \\
\hline Çevre & 0 & 13 & 0 & 17 & 0 & 30 \\
\hline Ekonomi & 29 & 0 & 7 & 0 & 36 & 0 \\
\hline Bilim & 0 & 0 & 0 & 1 & 0 & 1 \\
\hline Teknoloji & 0 & 0 & 2 & 0 & 2 & 0 \\
\hline Etik/Ahla & 0 & 0 & 0 & 0 & 0 & 0 \\
\hline Politik & 0 & 0 & 0 & 0 & 0 & 0 \\
\hline
\end{tabular}


Tablo 7 genel olarak incelendiğinde nükleer santral yapımını destekleyen katılımcıların $\mathrm{KÇ}$ gerekçelerinin ekonomi ( $\mathrm{f}=36)$ boyutunda, desteklemeyen katılımcıların ise çevre $(\mathrm{f}=30)$ boyutunda yoğunlaştığı görülmektedir. Program bazında ise nükleer santral yapımını destekleyen İlahiyat öğrencilerinin ekonomi $(\mathrm{f}=29)$ boyutu dişında sadece sosyoloji $(\mathrm{f}=2)$ boyutunda $\mathrm{KÇ}$ gerekçe ürettikleri diğer boyutlarda üretmedikleri görülmektedir. Ayrıca nükleer santralin yapılmasını isteyen üç $(n=3)$ ilahiyat öğrencisi örnek ifade de görüldüğü gibi herhangi bir boyut altında ele alınamayacak şekilde gerekçelerini ifade etmişlerdir.

\section{“yararlarının zararlarından çok olduğunu düşündüğüm için destek veriyorum (İ12).”}

Yapıma karşı olan ilahiyat öğrencilerinin ise sadece çevre $(\mathrm{f}=13)$ boyutunda KÇ gerekçe ürettikleri görülmektedir. Nükleer santral yapımını destekleyen Fen Bilgisi öğrencilerinin ise ekonomi $(\mathrm{f}=7)$ boyutu dışında sadece teknoloji $(\mathrm{f}=2)$ boyutunda $\mathrm{KÇ}$ gerekçe ürettikleri diğer boyutlarda üretmedikleri, yapılmamalı diyenlerin ise çevre $(\mathrm{f}=17)$ ve bilim $(\mathrm{f}=1)$ boyutlarında $\mathrm{KÇ}$ gerekçe ürettikleri görülmektedir. Katılımcıların nükleer santral ile ilgili PK'larının SÇE-BTEP modeline göre dağılımı Tablo 8' de sunulmuştur.

Tablo 8.

Katılımcıların PK'larının SÇE-BTEP Modeline Göre Dağılımı

\begin{tabular}{|c|c|c|c|c|c|c|}
\hline \multirow[b]{3}{*}{ Boyutlar } & \multicolumn{2}{|c|}{ İlahiyat } & \multicolumn{2}{|c|}{ Fen Bilgisi } & \multicolumn{2}{|c|}{ Toplam } \\
\hline & Yapılmal & Yapılmamal & Yapılmal & Yapilmamal & Yapilmal & Yapilmamal \\
\hline & $\begin{array}{c}1 \\
(f)\end{array}$ & $\begin{array}{c}1 \\
\text { (f) }\end{array}$ & $\begin{array}{c}1 \\
(f)\end{array}$ & $\begin{array}{c}1 \\
(f)\end{array}$ & $\begin{array}{c}1 \\
(f)\end{array}$ & $\begin{array}{c}1 \\
\text { (f) }\end{array}$ \\
\hline Sosyoloji & 3 & 0 & 2 & 0 & 5 & 0 \\
\hline Çevre & 0 & 7 & 0 & 20 & 0 & 27 \\
\hline Ekonomi & 17 & 0 & 8 & 4 & 25 & 4 \\
\hline Bilim & 0 & 0 & 0 & 5 & 0 & 5 \\
\hline Teknoloji & 1 & 0 & 0 & 0 & 1 & 0 \\
\hline $\begin{array}{l}\text { Etik/Ahla } \\
\mathrm{k}\end{array}$ & 0 & 1 & 0 & 2 & 0 & 3 \\
\hline Politik & 0 & 0 & 1 & 0 & 1 & 0 \\
\hline Toplam & 24 & 8 & 11 & 31 & 32 & 39 \\
\hline
\end{tabular}

Tablo 8 genel olarak incelendiğinde nükleer santral yapımını destekleyen katılımcıların PK'larının KÇ gerekçelere benzer şekilde ekonomi (f=25) boyutunda, desteklemeyen katılımcıların ise çevre ( $\mathrm{f}=27)$ boyutunda yoğunlaştığı görülmektedir. Program bazında ise nükleer santral yapımını destekleyen ilahiyat öğrencilerinin en fazla ekonomi ( $\mathrm{f}=17)$, sonrasında ise sosyoloji $(\mathrm{f}=3)$ ve teknoloji $(\mathrm{f}=1)$ boyutlarında PK kullandıkları, karşı olanların ise çevre $(\mathrm{f}=7)$ ve etik $(\mathrm{f}=1)$ boyutlarında $\mathrm{PK}$ kullandıkları görülebilmektedir. Bununla birlikte ilahiyat öğrencileri bilim ve politik boyutlarda PK kullanmamışlardır. Nükleer santral yapımını destekleyen Fen Bilgisi öğrencilerinin ise ekonomi $(\mathrm{f}=8)$ boyutu dışında sosyoloji $(\mathrm{f}=2)$ ve politik $(\mathrm{f}=1)$ boyutlarda PK ürettikleri diğer boyutlarda üretmedikleri belirlenmiştir. Bunun yanında nükleer santralin yapımını istemeyen Fen Bilgisi öğrencilerinin ürettikleri PK'lar ise en fazla çevre ( $\mathrm{f}=20)$ sonrasında ise sirasiyla bilim $(\mathrm{f}=5)$, ekonomi $(\mathrm{f}=4)$ ve etik $(\mathrm{f}=2)$ boyutlarında oldukları görülmektedir. Fen bilgisi öğrencileri sadece teknoloji boyutunda PK üretmemişlerdir. Katılımcıların nükleer santral ile ilgili NK' larının SÇE-BTEP modeline göre dağılımı Tablo 9' da sunulmuştur.

Tablo 9 genel olarak incelendiğinde nükleer santral yapımını destekleyen katılımcıların NK'larının çevre ( $\mathrm{f}=16$ ) boyutunda, desteklemeyen katılımcıların ise ekonomi ( $\mathrm{f}=18)$ boyutunda yoğunlaştığı görülmektedir. Program bazında ise nükleer santral yapımını destekleyen ilahiyat öğrencilerinin sadece çevre ( $\mathrm{f}=12)$ NK kullandıkları, karşı olanların ise ekonomi $(\mathrm{f}=5)$ ve teknoloji $(\mathrm{f}=3)$ boyutlarında NK kullandıkları görülebilmektedir. Bununla birlikte ilahiyat 
öğrencileri sosyoloji, bilim, etik ve politik boyutlarda NK kullanmamışlardır. Nükleer santral yapımını destekleyen Fen Bilgisi öğrencilerinin ise çevre $(f=4)$ boyutu dışında ekonomi $(f=1)$ ve bilim $(\mathrm{f}=1)$ boyutlarda NK ürettikleri diğer boyutlarda üretmedikleri, yapılmamalı diyenlerin ise en fazla ekonomi $(\mathrm{f}=13)$, teknoloji $(\mathrm{f}=1)$ ve politik $(\mathrm{f}=1)$ boyutlarda NK ürettikleri diğer boyutlarda ise kullanmadıkları görülmektedir.

Tablo 9.

Katılımcıların NK'larının SÇE-BTEP Modeline Göre Dağılımı

\begin{tabular}{|c|c|c|c|c|c|c|}
\hline & \multicolumn{2}{|c|}{ İlahiyat } & \multicolumn{2}{|c|}{ Fen Bilgisi } & \multicolumn{2}{|c|}{ Toplam } \\
\hline & Yapılmal & Yapılmamal & Yapılmal & Yapılmamal & Yapılmal & Yapılmamal \\
\hline Boyutlar & $\begin{array}{c}1 \\
\text { (f) }\end{array}$ & $\begin{array}{c}1 \\
\text { (f) }\end{array}$ & $\begin{array}{c}1 \\
\text { (f) }\end{array}$ & $\begin{array}{c}1 \\
\text { (f) }\end{array}$ & $\begin{array}{c}1 \\
\text { (f) }\end{array}$ & $\begin{array}{c}1 \\
\text { (f) }\end{array}$ \\
\hline Sosyoloji & 0 & 0 & 0 & 0 & 0 & 0 \\
\hline Cevre & 12 & 0 & 4 & 0 & 16 & 0 \\
\hline Ekonomi & 0 & 5 & 1 & 13 & 1 & 18 \\
\hline Bilim & 0 & 0 & 1 & 0 & 1 & 0 \\
\hline Teknoloji & 0 & 3 & 0 & 1 & 0 & 4 \\
\hline $\begin{array}{l}\text { Etik/Ahla } \\
\mathrm{k}\end{array}$ & 0 & 0 & 0 & 0 & 0 & 0 \\
\hline Politik & 0 & 0 & 0 & 1 & 0 & 1 \\
\hline Toplam & 12 & 8 & 6 & 15 & 18 & 23 \\
\hline
\end{tabular}

Katılımcıların PK ve NK oluşturabilme düzeylerinin betimsel istatistikleri Tablo 10 da sunulmuştur.

Tablo 10.

Katılımcıların PK, NK ve KK Oluşturabilme Düzeylerinin Betimsel İstatistikleri

\begin{tabular}{llccc}
\hline & & Ortalama & N & SS \\
\hline İlahiyat Öğrencileri & PK & 0.62 & 47 & 0.68 \\
& NK & 0.43 & 47 & 0.62 \\
\multirow{4}{*}{ Fen Bilgisi Ö ğretmenliği } & KK & 0.15 & 47 & 0.36 \\
& PK & 1.56 & 27 & 0.93 \\
& NK & 0.78 & 27 & 0.85 \\
Genel & KK & 0.33 & 27 & 0.48 \\
& PK & 0.96 & 74 & 0.90 \\
& NK & 0.55 & 74 & 0.72 \\
& KK & 0.22 & 74 & 0.41 \\
\hline
\end{tabular}

Tablo 10'da görüldüğü üzere katılımcıların oluşturdukları PK, NK ve KK ortalamaları sirasıyla $0.96(\mathrm{ss}=0.90), 0.55,(\mathrm{ss}=0.72)$ ve $0.22(\mathrm{ss}=0.41)$ bulunmuştur. Katılımc1lar kararlarını gerekçelendirmek için NK'dan $(\bar{X}=0.55)$ daha çok PK $(\bar{X}=0.96)$ oluşturmuşlardır ve bu fark istatistiksel olarak anlamlıdır $(\mathrm{t}(73)=3.34, \mathrm{p}=0.01)$. Katılımc1ların kayıtlı oldukları bölüme göre oluşturdukları PK, NK ve KK sayılarına bakıldığında İlahiyat öğrencileri ortalama 0.62 ( $\mathrm{ss}=0.68$ ) PK oluşturmuş iken aynı öğrenciler ortalama $0.43(\mathrm{ss}=0.62) \mathrm{NK}$ ve ortalama $0.15(\mathrm{ss}=0.36) \mathrm{KK}$ oluşturmuşlardır. İlişkili örneklem t-testi sonuçları İlahiyat Fakültesi öğrencilerinin oluşturdukları PK ve NK sayılarının birbirinden farkının istatistiksel olarak anlamlı olmadığını göstermektedir $(\mathrm{t}(46)=1.46, \mathrm{p}=0.15)$. Bunun yanında Fen bilgisi öğretmenliği programına kayıtlı öğrencilerin oluşturdukları PK, NK ve KK ortalamaları sirasıyla $1.56(\mathrm{ss}=0.93), 0.78$ ( $\mathrm{ss}=0.85$ ) ve 0.33 $(\mathrm{ss}=0.48)$ olarak hesaplanmıştır. İlişkili örneklem t-testi yapıldığında Fen bilgisi öğrencilerinin PK ve NK sayıları arasındaki fark istatistiksel olarak anlamlı olduğu görülmüştür $(t(26)=3.40$, 
$\mathrm{p}=0.00)$. Katılımcıların $\mathrm{PK}$, NK ve KK oluşturabilme düzeylerinin lisans değişkenine göre bağımsız örneklem t-testi bulguları Tablo 11'de sunulmuştur.

Tablo 11.

Katılımcıların PK, NK ve KK Oluşturabilme Düzeylerinin Lisans Değişkenine Göre Bağımsız Örneklem t-testi

\begin{tabular}{llccl}
\hline & Ortalama fark1 & $\mathrm{t}$ & $\mathrm{Sd}$ & $P$ \\
\hline İlahiyat- Fen Bilgisi Öğgretmenliği PK & -0.94 & -4.99 & 72 & $.00^{*}$ \\
İlahiyat- Fen Bilgisi Öğretmenliği NK & -0.35 & -2.06 & 72 & $.04^{*}$ \\
İlahiyat- Fen Bilgisi Öğgretmenliği KK & -0.18 & -1.87 & 72 & .07 \\
\hline *
\end{tabular}

$* \mathrm{p}$ değeri 0.05 seviyesinde anlamlı (2 tailed)

Betimsel istatistikler İlahiyat öğrencilerinin Fen Bilgisi öğrencilerinden daha az PK, NK ve KK oluşturduklarını göstermektedir. Uygulanan bağımsız örneklem t-testi sonuçları İlahiyat öğrencilerinin ve Fen Bilgisi öğrencilerinin PK $(\mathrm{t}(72)=-4.99, \mathrm{p}=0.00)$ ve $\mathrm{NK}(\mathrm{t}(72)=-2.06$, $\mathrm{p}=0.04$ ) oluşturma seviyelerinin farkının istatistiksel olarak anlamlı olduğunu göstermektedir. $\mathrm{Bu}$ farklılık Fen Bilgisi öğrencilerinin lehinedir. Ancak bağımsız örneklem t-testi İlahiyat öğrencilerinin oluşturdukları KK ile Fen Bilgisi öğrencilerinin oluşturdukları KK seviyeleri arasında bulunan farkın istatistiksel olarak anlamlı olmadığını ortaya koymuştur $(\mathrm{t}(72)=-1.87$, $\mathrm{p}=0.07)$. Katılımcıların nükleer santrali destekleme durumuna göre PK ve NK düzeylerinin betimsel istatistikleri Tablo 12' de sunulmuştur.

Tablo 12.

Nükleer Santrali Desteklemeye Göre Katılımcıların PK ve NK Oluşturabilme Düzeylerinin Betimsel İstatistikleri

\begin{tabular}{llccc}
\hline & & Ortalama & N & SS \\
\hline Yapilsin & PK & 0.76 & 42 & 0.12 \\
& NK & 0.45 & 42 & 0.10 \\
Yapilmasin & PK & 1.22 & 32 & 0.17 \\
& NK & 0.69 & 32 & 0.15 \\
\hline
\end{tabular}

Katılımcıların PK ve NK oluşturma seviyeleri nükleer santrali destekleme durumuna göre incelendiğinde nükleer santralin yapılması yönünde oy kullanan katılımcılar ortalama 0.76 ( ss= 0.12) PK oluştururken NK oluşturma ortalamaları $0.45(\mathrm{ss}=0.10)$ olmuştur. Yapılan ilişkili örneklem t-testi neticesinde nükleer santralin yapılması yönünde oy kullanan katılımcıların PK oluşturma seviyeleri NK'larından fazla olmasına rağmen ikisi arasında istatistiksel olarak anlamlı bir fark olmadığı bulunmuştur $(\mathrm{t}(41)=1.96, \mathrm{p}=0.06)$. Bunun yanında nükleer santralin yapılmaması yönünde oy kullanan katılımcıların oluşturdukları PK ve NK ortalamaları sırasıyla $1.22(\mathrm{ss}=0.17)$ ve $0.69(\mathrm{ss}=0.15)$ olarak gerçekleşmiştir. Nükleer santralin yapıllmaması yönünde oy kullanan katılımcıların oluşturdukları PK sayıları NK sayılarından fazladır ve bu farkın yapılan ilişkili örneklem t-testi ile anlamlı olduğu bulunmuştur $(\mathrm{t}(31)=2.79, \mathrm{p}=0.01)$.

Tablo 13.

Katılımcıların PK ve NK Oluşturabilme Düzeylerinin Nükleer Santrale Verdikleri Desteğe Göre Bağımsız Örneklem T-Testi

\begin{tabular}{llccc}
\hline & Ortalama fark1 & $\mathrm{t}$ & $\mathrm{Sd}$ & $P$ \\
Yapılsın- Yapılmasin PK & -0.46 & -2.23 & 72 & $.03^{*}$ \\
Yapılsın- Yapılmasin NK & -0.24 & -1.39 & 72 & .17 \\
\hline
\end{tabular}

Katılımcıların oluşturdukları PK ve NK sayıları kullandıkları oy türüne göre karşılaştırıldığında nükleer santralin yapılmasını isteyenlerin oluşturdukları PK sayıları 
istemeyenlerin oluşturdukları PK sayılarından azdır. Yapılan bağımsız örneklem t-testi bu farkın istatistiksel olarak anlamlı olduğunu göstermektedir $(\mathrm{t}(72)=-2.23, \mathrm{p}=0.03)$. Benzer olarak nükleer santralin yapılmasını isteyenlerin oluşturdukları NK sayıları istemeyenlerden az olduğu Tablo 12 'de görülmektedir. Ancak yapılan bağımsız örneklem t-testi bu farkın istatistiksel olarak anlamlı olmadığını göstermektedir $(\mathrm{t}(72)=-1.39, \mathrm{p}=0.17)$.

\section{Tartışma ve Sonuç}

Araştırma bulguları dikkate alındığında üniversite öğrencilerinin eğitim gördükleri lisans programlarının Nükleer Santral SBK ile ilgili kararlarında istatiksel olarak anlamlı bir farklılığa neden olduğu görülmektedir. İlahiyat fakültesinde öğrenim görmekte olan lisans öğrencileri istatiksel olarak anlamlı bir fark ile nükleer santralin kurulmasını, fen bilgisi öğretmenliği öğrencileri ise kurulmamasını istemektedirler. Alan yazın incelendiğinde lisans öğrencilerinin SBK ile ilgili kararlarının genelde öğretmen adayları ile yapılan çalışmalarda (Eş, Işık Mercan ve Ayas, 2016; Özdemir ve Çobanoğlu, 2008) ele alındığı ve bu araştırmalarda da öğrenim gördükleri programlarda aldıkları derslere bağlı olarak öğretmen adaylarının kararlarının farklılaştığı ifade edilmektedir. Bunlara ek olarak daha alt öğrenim basamaklarında yapılan araştırmalarda ise katılımcıların aynı bilgiye erişmelerine rağmen bu bilgileri farklı şekilde değerlendirerek kararlarını oluşturdukları da görülmüş̧ür (Rundgren, Eriksson ve Chang Rundgren, 2016). Bu farklı değerlendirmelerin bireylerin temel inançlarındaki (Kolstø 2006) ve entelektüel birikimlerindeki farklılıklardan (Zeidler, 1997) kaynaklanabileceği belirtilmektedir. $\mathrm{Bu}$ farklılaşma SBK'nın kesin bir cevabı olmayan, tartışmalı ve ikilemli doğası dikkate alındığında normal bir durum olarak karşılanabilir.

Katılımcıların Nükleer Santral SBK ile ilgili ürettikleri argümanlar incelendiğinde ise nükleer santrale destek veren öğrencilerin KÇ gerekçelerinin ve PK'larının ekonomi boyutunda yoğunlaştı̆g karşı olanların KÇ gerekçelerinin ve PK'larının çevre boyutunda, nükleer santral yapımını destekleyen katılımcıların NK' larının çevre boyutunda, desteklemeyen katılımcıların ise NK'larının ekonomi boyutunda yoğunlaştı̆̆ 1 görülmüştür. SBK doğası gereği çok boyutlu bir yapıya sahiptir ve lisans düzeyinde öğrenim görmekte olan öğrencilerin herhangi bir SBK'yı ele alırken çok boyutlu değerlendirme yapabilmeleri beklenmektedir. Ancak araştırma bulguları katılımcıların PK ve NK'larının ekonomi ve çevre boyutlarında yoğunlaştığını diğer boyutlarda ise ya çok az sayıda ya da hiç üretilmediğini ortaya koymaktadır. Öyle ki katılımcıların hiçbiri sosyoloji ve etik boyutlarında NK üretmemiştir. Etik boyut ile ilgili benzer bir sonuç Christenson, Rundgren ve Höglund (2012)'in araştırmalarında da görülmektedir. Bununla birlikte SBK'nın çok boyutlu yapısı üzerinde önemle durulmaktadır (Sadler ve Donnelly 2006; Zeidler ve Keefer 2003). Bu bağlamda araştırma kapsamında önerilen SÇE-BTEP modeli SBK'nın çok boyutlu yapısının fark edilebilmesi ve çeşitli kademelerde öğrenim görmekte olanların farklı boyutlarda gerekçe üretmeye teşvik edilmeleri açısından önemli bir araç olarak kullanılabilir.

Araştırma bulguları incelendiğinde katılımcıların istatistiksel olarak anlamlı bir fark ile NK' dan daha fazla PK oluşturdukları görülmüştür. Bu sonuç katılımcıların kendi pozisyonlarını destekleyen kanıtlara odaklanma eğiliminden ve bu durumda karşı argümanları görmeme eğiliminden (Evagorou, Jimenez-Alexandre ve Osborne, 2012) kaynaklanıyor olabilir. Bu bağlamda araştırma kapsamında önerilen Lakatos'un Bilimsel Araştırma Programları SBK'nın ikilemler içeren tartışmalı yapısının fark edilebilmesi ve çeşitli kademelerde öğrenim görmekte olanların SBK'nın bu özelliklerine uygun olarak PK'ların yanında NK üretmeye teşvik edilmeleri açısından önemli bir araç olarak kullanılabilir.

Araştırma bulguları İlahiyat öğrencilerinin Fen Bilgisi öğrencilerinden istatistiksel olarak anlamlı bir şekilde daha az PK ve NK oluşturduklarını göstermektedir. Fen bilgisi öğretmen adaylarının daha fazla PK ve NK üretmesi lisans programlarında çeşitli derslerde Argümantasyon ve SBK ile ilgili eğitim almaları ile açıklanabilir. Benzer bir sonuç Chang ve Chiu'in (2008) Sağlık Bilimleri ve Güzel Sanatlar lisans öğrencileri ile yaptıkları araştırmada da ortaya çıkmıştır. Bahsi geçen çalışmada araştırmacılar, bilim alanında eğitim alan (Sağlık Bilimleri) öğrencilerin argümantasyon becerilerinin bilim dışı alanda (Güzel Sanatlar) eğitim alan öğrencilerin becerilerinden daha iyi olduğunu ifade etmektedirler. Yapılan araştırmalar (Means ve Voss, 1996; 
Sadler ve Zeidler, 2004; Tytler, Duggan, ve Gott, 2001) sahip olunan bilgilerin informal gerekçelendirme ve argümantasyon becerilerini olumlu yönde etkilediğini göstermektedir. Hangi eğitim seviyesinde ya da hangi alanda eğitim aldığına bakılmaksızın günümüzde tüm bireyler çeşitli SBK ile ilgili eleştirel düşünme ve karar verme becerilerini işe koşmak zorunda kalabilmektedirler (Chang Rundgren ve Rundgren, 2010). Bu durum da tüm bireylerin fen okuryazarı olma zorunluluğunu ortaya çıkarmaktadır. Bu gerekçelerle çeşitli eğitim kademe ve alanlarında bireylerin eleştirel düşünme ve karar verme becerilerini geliştirmek amacıyla önemli bir bağlam olarak SBK değerlendirilebilir.

Bir bireyin iyi düzeyde informal argümantasyon becerisine sahip olduğunun kabul edilmesi için Lakatos'un bilimsel programlarının bileşenlerinin tamamını kullanması gerekmektedir (Chang ve Chiu, 2008). Ancak yetmiş dört katılımeının sadece on altısı KK kullanmıştır. Bu katılımcıların yedisi İlahiyat, dokuzu ise Fen Bilgisi Öğretmenliği öğrencisidir. $\mathrm{Bu}$ sonuç katılımcıların öğrenim gördüğü lisans programı fark etmeksizin büyük çoğunluğunun iyi düzeyde informal argümantasyon becerisine sahip olmadığı anlamına gelmektedir.

Araştırma sonuçları dikkate alındığında lisans öğrencilerinin büyük çoğunluğunun iyi düzeyde informal argümantasyon becerisine sahip olmadığı ve SBK'nın çok boyutlu yapısına uygun argüman üretemediği görülmektedir. Bu gerekçelerle çeşitli eğitim kademe ve alanlarında bireylerin eleştirel düşünme, karar verme ve argümantasyon becerilerini geliştirmek amaciyla Lakatos'un bilimsel araştırma programları ve SÇE-BTEP modeli kullanılabilir.

\section{Kaynaklar}

Bell, R. L. ve Lederman, N. G. (2003). Understandings of the nature of science and decision making on science and technology based issues. Science Education, 87(3), 352-377.

Bossér, U., Lundin, M., Lindahl, M. ve Linder, C. (2015). Challenges faced by teachers implementing socio-scientific issues as core elements in their classroom practices. European Journal of Science and Mathematics Education, 3(2), 159-176.

Chang Rundgren, S. N. (2011). Post it!-A cross-disciplinary approach to teach socioscientific issues. Teaching Science, 57(3), 25.

Chang Rundgren, S. N. ve Rundgren, C. J. (2010). SEE-SEP: From a separate to a holistic view of socioscientific issues. Asia-Pacific Forum on Science Learning \& Teaching, (11).

Chang, S. N. ve Chiu, M. H. (2008). Lakatos' scientific research programmes as a framework for analysing informal argumentation about socio-scientific issues. International Journal of Science Education, 30(13), 1753-1773.

Christenson, N., Rundgren, S. N. C. ve Höglund, H. O. (2012). Using the SEE-SEP model to analyze upper secondary students' use of supporting reasons in arguing socioscientific issues. Journal of Science Education and Technology, 21(3), 342-352.

Driver, R., Newton, P. ve Osborne, J. (2000). Establishing the norms of scientific argumentation in classrooms. Science Education, 84, 287-312.

Eggert, S. ve Bögeholz, S. (2010). Students' use of decision-making strategies with regard to socioscientific issues: An application of the Rasch partial credit model. Science Education, 94(2), 230-258.

Erduran, S., Simon, S. ve Osborne, J. (2004). TAPping into argumentation: Developments in the application of Toulmin's argument pattern for studying science discourse. Science Education, 88(6), 915-933.

Eş, H. (2017, October). Fen bilimleri öğretmen adaylarının fen, bilim ve teknoloji kavramları ile ilgili görüşleri. II. International academic research congress, Alanya, Türkiye. Erişim adresi: researchgate.net/profile/Hueseyin_Es2/research

Eş, H. ve Varol, V. (2018, April). The pre-service science teachers' arguments about a socioscientific issue -nuclear energy-. International Conference on Education in Mathematics, Science \& Technology (ICEMST), içinde (ss. 160) Marmaris, Turkey. Erişim adresi: 2018.icemst.com/ckfinder/upload/files/ICEMST2018_AbstractBook.pdf?v=03052018

Eş, H., Işı1k Mercan, S. ve Ayas, C. (2016). Türkiye için yeni bir sosyo-bilimsel tartışma: Nükleer ile yaşam. Turkish Journal of Education, 5(2), 47-59. 
Evagorou, M., Jimenez-Alexandre, M. P. ve Osborne, J. (2012). 'Should we kill the grey squirrels?' a study exploring students' justifications and decision-making. International Journal of Science Education, 34(3), 401-428.

Grace, M. M. ve Ratcliffe, M. (2002). The science and values that young people draw upon to make decisions about biological conservation issues. International Journal of Science Education, 24, 1157-1169.

Halpern, D. F. (1996). Thought and knowledge: An introduction to critical thinking. Hillsdale, NJ: Erlbaum.

Hodson, D. (2003). Time for action: Science education for an alternative future. International journal of science education, 25(6), 645-670.

Jimenez-Aleixandre, M. P. (2002). Knowledge producers or knowledge consumers? Argumentation and decision making about environmental management. International Journal of Science Education, 24(11), 1171-1190.

Kelly, G. J. ve Chen, C. (1999). The sound of music: Constructing science as sociocultural practice through oral and written discourse. Journal of Research in Science Teaching, 36(8), 883-915.

Kelly, G.J., Druker, S. ve Chen, C. (1998). Students' reasoning about electricity: Combining performance assessments with argumentation analysis. International Journal of Science Education, 20(7), 849-871.

Kolst $\varnothing$, S. D. (2006). Patterns in students' argumentation confronted with a risk-focused socioscientific issue. International Journal of Science Education, 28(14), 1689-1716.

Kuhn, D. (1991). The skills of arguments. Cambridge, England: Cambridge University Press.

Kuhn, D. (1993). Science as argument: Implications for teaching and learning scientific thinking. Science Education, 77(3), 319-337.

Lakatos, I. (1970). Falsification and the methodology of scientific research programmes. I. Lakatos ve A. Musgrave (Yay. haz.), Criticism and The Growh of Knowledge içinde (ss. 91-195). New York: Cambridge University Press.

Lee, Y. C. (2007). Developing decision-making skills for socio-scientific issues.Journal of Biological Education, 41(4), 170-177.

Means, M. L. ve Voss, J. F. (1996). Who reasons well? Two studies of informal reasoning among children of different grade, ability, and knowledge levels. Cognition and Instruction, 14(2), 139-178.

Miles, M. B. ve Huberman, A. M. (1994). Qualitative data analysis. London: Sage Publication.

Milli Eğitim Bakanlığı (MEB), (2005). İlköğretim fen ve teknoloji dersi 4., 5., 6., 7. ve 8. sinıflar ögretim programı. Ankara: MEB.

Nickerson, R. S. (1991). Modes and models of informal reasoning: A commentary. J. F. Voss, D. N. Perkins ve J. W. Segal (Yay. haz.). Informal Reasoning and Education içinde (ss. 291309). Hillsdale, NJ: Lawrence Erlbaum Associates.

Nussbaum, M. E. (2002). Scaffolding argumentation in the social studies classroom. Social Studies, 93(3), 79-85.

Osborne, J., Erduran, S. ve Simon, S. (2004). Enhancing the quality of argumentation in school science. Journal of Research in Science Teaching, 41(10), 994-1020.

Özdemir, N. ve Çobanoğlu, E. O. (2008). Türkiye' de nükleer santrallerin kurulması ve nükleer enerji kullanımı konusundaki öğretmen adaylarının tutumları. Hacettepe Üniversitesi Ĕ̈itim Fakültesi Dergisi, 34, 218- 232.

Patton, M. Q. (2014). Nitel araştırma ve değerlendirme yöntemleri. M. Bütün ve S. B. Demir (Çev.). Ankara: Anı Yayıncılık.

Perkins, D. N., Faraday, M. ve Bushey, B. (1991). Everyday reasoning and the roots of intelligence. J. F. Voss, D. N. Perkins ve J. W. Segal (Yay. haz.). Informal Reasoning and Education içinde (ss. 83-105). Hillsdale, NJ: Lawrence Erlbaum.

Presley, M. L., Sickel, A. J., Muslu, N., Merle-Johnson, D., Witzig, S. B., Izci, K. ve Sadler, T. D. (2013). A framework for socio-scientific issues based education. Science Educator, 22, 26-32. 
Rundgren, C. J., Eriksson, M. ve Chang Rundgren, S. N. (2016). Investigating the intertwinement of knowledge, value, and experience of upper secondary students' argumentation concerning socioscientific issues. Science \& Education, 25(9-10), 1049-1071.

Sadler, T. D. (2003). Informal reasoning regarding socioscientific issues: The influence of morality and content knowledge (Unpublished doctoral dissertation).University of South Florida, USA.

Sadler, T. D. (2004a). Informal reasoning regarding socioscientific issues: A critical review of research. Journal of Research in Science Teaching, 41(5), 513-536.

Sadler, T. D. (2004b). Moral and ethical dimensions of socioscientific decision-making as integral components of scientific literacy. Science Educator, 13(1), 39-48.

Sadler, T. D. ve Donnelly, L. A. (2006). Socioscientific argumentation: The effects of content knowledge and morality. International Journal of Science Education, 28(12), 1463-1488.

Sadler, T. D. ve Zeidler, D. L. (2004). The morality of socioscientific issues: Construal and resolution of genetic engineering dilemmas. Science Education, 88, 4-27.

Sadler, T. D. ve Zeidler, D. L. (2005). Patterns of informal reasoning in the context of socioscientific decision-making. Journal of Science Teacher Education, 17, $217-241$.

Simonneaux, L. (2001). Role-play or debate to promote students' argumentation and justification on an issue in animal transgenesis. International Journal of Science Education, 23(9), 903-927.

Tirri, K. ve Pehkonen, L. (2002). The moral reasoning and scientific argumentation of gifted adolescents. The Journal of Secondary Gifted Education, 8(3), 120-129.

Tytler, R., Duggan, S. ve Gott, R. (2001). Dimensions of evidence, the public understanding of science and science education. International Journal of Science Education, 23, 815-832.

Voss, J. F. (1991). Informal reasoning and international relationship. J. F. Voss, D. N. Perkins ve J. W. Segal (Yay. haz.). Informal reasoning and education. Hillsdale, NJ: Lawrence Erlbaum Associates.

Voss, J. F. ve Means, M. L. (1991). Learning to reason via instruction in argumentation. Learning and Instruction, 1, 337-350.

Voss, J. F., Perkins, D. ve Segal, J. (1991). Informal reasoning and education. Hillsdale, NJ: Lawrence Erlbaum Associates.

Zeidler, D. (1997). The central role of fallacious thinking in science education. Science Education, 81(4), 483-496.

Zeidler, D. L. ve Keefer, M. (2003). The role of moral reasoning and the status of socioscientific issues in science education: Philosophical, psychological and pedagogical considerations. D. L. Zeidler (Yay. haz.). The role of moral reasoning on socioscientific issues and discourse in science education. The Netherlands: Kluwer Academic Press.

Zeidler, D. L., Sadler, D. T., Simmons, M. L. ve Howes, E. V. (2005). Beyond STS: A researchbased framework for socioscientific issues education. Science Education, 89, 357-377.

Zeidler, D. L., Walker, K. A., Ackett,W. A. ve Simmons, M. L. (2002). Tangled up in views: Beliefs in the nature of science and responses to socioscientific dilemmas. Science Education, 86(3), 343-367.

Zohar, A. ve Nemet, F. (2002). Fostering students' knowledge and argumentation skills through dilemmas in human genetics. Journal of Research in Science Teaching, 39(1), 35-62.

\section{Extended Abstract \\ Introduction}

The issues such as cloning, stem cell studies, genome project, global warming, alternative fuels (Sadler, 2004a; Sadler \& Zeidler, 2005; Sadler \& Donnelly, 2006) climate change, nuclear energy, which exist in society open-ended (Presley et al., 2013), create a dilemma between individuals and bring together society, science and technology, are defined as socio-scientific issues (SSI) (Sadler, 2004a). Individuals may have to apply critical thinking and decision making skills on certain socio-scientific issues (Chang Rundgren \& Rundgren, 2010). In this process, it has been emphasized that SSI is an important context for individuals to improve their discussing, reasoning 
and decision-making skills and making informed decisions on social issues from social, political and scientific point of view, namely, they gain scientific literacy (Hodson, 2003; Sadler \& Zeidler, 2005; Zohar \& Nemet, 2002). People have to make judgments and make a conclusion based on their beliefs or evidence they have in their lives (Kuhn, 1993). As a result of this, argumentation skills have become very important for modern citizens and professionals, and they need to be acquired in schools (Driver, Newton \& Osborne, 2000; Nussbaum, 2002). Although the importance of argumentation skills is known, it is still uncertain exactly how much these students have these skills. Therefore, it is a necessity to investigate the students' level of argumentation skills. In line with these reasons, this study was conducted in order to examine the argumentation skills of the students studying in different undergraduate programs (theology and science education).

\section{Method}

The study group consisted of, forty-seven (47) Theology students, twenty-seven (27) Science Education students, Faculty of Education, in the total of seventy-four (74) undergraduate students. The purpose of selecting theology and science education students in the study group was to compare the informal argumentation skills of the undergraduate students mainly studying religion and students studying science. The data collection tool of this study is the Nuclear Energy Decision and Evaluation Form (NEDEF), which consists of three questions, two of which are closed and one of which is open-ended. The Nuclear Energy Decision and Evaluation Form (NEDEF) contains brief information about the specifications of the nuclear power plant that are planned to be built in Sinop. After this brief information, the participants were asked 2 closed questions. In the first question, there is a scale from zero $(0,1,2,3,4,5,6,7,8,9,10)$ to ten. In the scale, the number zero means that the installation of the nuclear power plant would not definitely happen, the number (5) means they are unsure, and the number (10) means the installation would definitely happen. The level of stability increases as it moves from number five, which is the indecisive value, to zero or ten. The participants were asked to mark their decisions on this scale. This way, it was aimed to find out about the stability of the participants' decisions. In the other question, the participants were asked "If there was a vote building a nuclear power plant in the city you are living in, what would you vote?" For this question, the participants were offered only two options; should be built and should not be built. This way, it was aimed to determine the hardcore (HC) claims of the participants. The third and last question of the Form is open-ended, and the participants were asked to discuss the positive and negative aspects of their decision. With analysing of the answers for this question, how many $\mathrm{HC}$ reasons, positive heuristic $(\mathrm{PH})$, negative heuristic $(\mathrm{NH})$ and protective Belt $(\mathrm{PB})$ were produced and used by the participants while they are defending their opinions. Answers of first two questions of the form were entered the SPSS-21 program as the participants filled. On the other hand, for the third question, content analysis was performed and then frequencies of the codes entered to SPSS-21 program. In the process of the content analysis of this study, in order to determine the informal argumentation skills of the participants, HC reason, PH, NH and PB developed by Chang and Chiu (2008) from the Lakatos' Scientific Research Programs were used. The participants' answers to the third question of NEDEF were analysed, and the related $\mathrm{HC}$ reason, $\mathrm{PH}, \mathrm{NH}$, and $\mathrm{PB}$ were defined. Afterward, $\mathrm{HC}$ reason, $\mathrm{PH}, \mathrm{NH}$ and $\mathrm{PB}$ the participants created, were offered to content analysis once more. The dimensions of SSI in HC reasons, $\mathrm{PH}, \mathrm{NH}$ and $\mathrm{PB}$ that the participants used, were analyzed using the SEE-STEP model developed from the SEE-SEP model of Sociology, Environment, Economy, Science, Ethics and Policy six subject areas developed by Chang Rundgren and Rundgren (2010). In the SEE-SEP model, technology was dealt with in science subject area and so evaluated like a science branch. However, even though technology and science are in close interaction, they are in fact different fields (Eş, 2017). Therefore, technology subject area has been added to SEE-SEP model and it was used as SEE-STEP model in this study. 


\section{Result and Discussion}

In general, thirty-two $(\mathrm{n}=32, \% 43.2)$ out of seventy-four $(\mathrm{N}=74)$ participants said nuclear power plant should not be built, whereas forty-two $(n=42, \% 56.8)$ of them said it should be built. When the scale of the participants was evaluated, the average support of those who voted for the establishment of the nuclear power plant was 8.64 (ss =1.65), whereas the support of those who voted for not to be established was found to be 1.25 ( $\mathrm{ss}=1.69$ ). The average of all participants was specified as 5.45 ( $\mathrm{ss}=4.04$ ), which is close to the unstable value (5). When the analysis were conducted in program basis, fourteen theology students $(n=14, \% 29.8)$ out of forty-seven said nuclear power plant should not be built, whereas thirty-three $(n=33, \% 70.2)$ of them said it should be built. On the other hand, eighteen science education students $(n=18, \% 67)$ out of twenty-seven have agreed on a nuclear power plant not to be built, whereas nine $(n=9, \% 33)$ stated it should be built. The analysis of the support for the establishment of the nuclear power plant in Sinop, the overall support of the theology and science education students is found $6.68(\mathrm{ss}=3.67)$ and 3.30 (ss $=3.80)$ respectively. These results indicate that theology students support the establishment of the nuclear power plant in Sinop than science education students and this difference is found to be statistically significant $(\mathrm{t}(72)=3.77, \mathrm{p}=0.00)$. The compression of the overall support of the participants with the value of 5 , the mean of the scale, indicate that both theology students $(\mathrm{t}(46)=3.14, \mathrm{p}=0.00)$, and science education students $(\mathrm{t}(26)=-2.33, \mathrm{p}=0.03)$ are found to be determined to support their ideas about establishment of the nuclear power plant in Sinop. When the participants' arguments about the SSI nuclear power plant were examined, supporting students produce $\mathrm{HC}$ reasons and PH's related to the economic issues, whereas $\mathrm{HC}$ and PK's of the students who were against the nuclear power plant, were focused on the environment. On the other hand, investigating the NH's of the participants show that supporting participants focus mostly on environment, whereas the participants who are against the establishment of the nuclear power plant focused on the economy. Socio-scientific issues (SSI) have multidimensional nature, and for undergraduate level students, it is expected to examine any kind of socio-scientific issue according to its multidimensional nature. However, the research findings show that PK and NK's of the participants were focused on the economy and environment and for other dimensions, they were either outnumbered or nonexistent. For example, none of the participants produced NH in terms of sociology or ethics. Christenson, Rundgren and Höglund (2012) found the similar result in their study that participants failed to produce NH's in ethics. Beside the quality of the produced $\mathrm{HC}, \mathrm{PH}, \mathrm{NH}$ and $\mathrm{PB}$, the quantity of these also were analyzed in this study as the multidimensional structure of SSI is emphasized in the literature (Sadler \& Donnelly 2006; Zeidler \& Keefer 2003). The overall produced $\mathrm{PH}, \mathrm{NH}$ and $\mathrm{PB}$ by the participants were found as 0.96 (ss=0.90), 0.55, $(\mathrm{ss}=0.72)$ and $0.22(\mathrm{ss}=0.41)$ respectively. The participants have created $\mathrm{PH}(\bar{X}=0.96)$ more than they have NH $(\bar{X}=0.55)$ in order to justify their decisions and this difference was statistically significant $(\mathrm{t}(73)=3.34, \mathrm{p}=0.01)$. When major variable considered the produced number of $\mathrm{PH}, \mathrm{NH}$, and PB by the participants differ. While Theology students created an average of $\mathrm{PH}$, $\mathrm{NH}$, and $\mathrm{PB}$ as 0.62 ( $\mathrm{ss}=0.68), 0.43(\mathrm{ss}=0.62)$ and 0.15 ( $\mathrm{ss}=0.36)$ respectively. The paired sample t-test results showed that the difference between $\mathrm{PH}$ and $\mathrm{NH}$ numbers of Theology students was not statistically significant $(\mathrm{t}(46)=1.46, \mathrm{p}=0.15$. On the other hand, the average $\mathrm{PH}, \mathrm{NH}$, and $\mathrm{PB}$ numbers of Science education students were found as $1.56(\mathrm{ss}=0.93), 0.78(\mathrm{ss}=0.85)$ and 0.33 $(\mathrm{ss}=0.48)$. When the paired sample t-test was performed for science major participants, it was seen that the difference between the average number of $\mathrm{PH}$ and $\mathrm{NH}$ of Science students produced was statistically significant $(\mathrm{t}(26)=3.40, \mathrm{p}=0.00)$. The means of $\mathrm{PH}, \mathrm{NH}$ and $\mathrm{PB}$ that theology students produced are less than science education students produced as stated above. Independent sample t-test was performed to determine whether the difference is statistically significant. The results showed that theology students produced significantly less $\mathrm{PH}(\mathrm{t}(72)=-4.99, \mathrm{p}=0.00)$ and $\mathrm{NH}(\mathrm{t}(72)=-2.06, \mathrm{p}=0.04)$ than science education students. However, the independent sample $\mathrm{t}-$ test revealed that the difference between the PB levels formed by Theology students and Science students was not statistically significant $(\mathrm{t}(72)=-1.87, \mathrm{p}=0.07)$. To be able accept individuals to have a good knowledge of informal argumentation skills, they must use all of the components in Lakatos' Scientific Research Programs (Chang and Chiu, 2008). However, only sixteen out of 
Eş ve Varol

seventy-four participants used PB. Seven of these participants were Theology, nine of them were Science Education students. This result means that the majority of the participants do not have a good level of informal argumentation skills, regardless of the degree program they study. When we look at the results of the study, it is seen that the majority of the undergraduate students do not have good informal argumentation skills and cannot create arguments good enough for multidimensional structure of SSI. For these reasons, Lakatos' Scientific Research Programs and SEE-STEP model can be used to develop critical thinking, decision making, and argumentation skills of individuals in various educational levels and fields. 